\author{
ACTA MYCOLOGICA \\ Vol. 44 (1): 43-48 \\ 2009
}

\title{
Volvariella caesiotincta P. D. Orton, a new species in the mycobiota of Poland
}

\author{
MAREK HALAMA \\ Museum of Natural History, Wrocław University \\ Sienkiewicza 21, PL-50-335 Wrocław, marhalam@biol.uni.wroc.pl
}

Halama M.: Volvariella caesiotincta P. D. Orton, a new species in the mycobiota of Poland. Acta Mycol. 44 (1): 43-48, 2009.

The article presents the first record of Volvariella caesiotincta P.D. Orton in Poland. Fruit body of the species was found on 22nd July 2002 in an oak-hornbeam/elm-ash municipal wood in the eastern part of Wrocław. The saproxylic Volvariella caesiotincta produced its carpophore on the base of rotten log of Quercus robur. The article brings closer taxonomic profile, ecological requirements and distribution pattern of the species. It also describes macroscopic and microscopic characteristics of the discovered specimens and presents the specification of habitat the fungus concerned.

Key words: Volvariella caesiotincta, macromycetes, urban greenery, Wrocław, SW Poland

\section{INTRODUCTION}

The genus Volvariella Speg. includes fungi with pluteoid habit of the carpophores, forming distinctive saccate velum universale at the base of central stipe. The saccate velum forms distinct memebranous volva, that usually breaks up into lobes with time (Boekhout 1990; Skirgiełł 1999). The genus includes species which are saprotrophic, terrestrial, wood occupying, or living on decaying agarics, cosmopolitan, or nearly so fungi. There are $c$. 50 described Volvariella species worldwide and 13 of them occuring in Europe (Kirk et al. 2008; Horak 2005; Singer 1986; Krieglsteiner 2003). There have been reported 9 species of the genus from Poland so far, i.e.: $V$. bombycina (Schaeff.: Fr.) Singer, V. gloiocephala (DC.: Fr.) Boekhout \& Enderle, $V$. hypopithys (Fr.) M. M. Moser, V. media (Schumach.: Fr.) Singer, V. murinella (Quél.) M. M. Moser, V. pusilla (Pers.: Fr.) Quél., V. surrecta (Knapp) Singer, V. taylorii (Berk. $\&$ Broome) Singer, and V. volvacea (Bull.: Fr.) Singer (Wojewoda 2003). Seven of the species mentioned above are on the red list of the macrofungi in Poland (Wojewoda, Lawrynowicz 2006). Volvariella caesiotincta P.D. Orton has never previously been 
found in Poland. However it should be noted, that after the author's record, V. caesiotincta was reported at least from one other (not legitimately published) locality within Polish area (Puszcza Niepołomicka Forest; Karasiński 2006).

\section{METHODS}

Material was gathered within urban greenery of Wrockaw. The investigated habitat was illustrated with a phytosociological record. The floristic composition and diversity of the forest community were studied using the Brown-Blanquet method. The nomenclature of forest communities follows Matuszkiewicz (2007); that of vascular plants follows Mirek et al. (2002). Microscopical slides of dried material were prepared with $5 \% \mathrm{NH}_{4} \mathrm{OH}$ and Congo red in $1 \%$ ammonia. The microcharacters of one recorded basidioma were observed and measured under a standard light microscope. Morphological measurements were quoted according to Breitenbach \& Kränzlin (1991). Terminology of morphological and anatomical elements was adapted from Vellinga (1988). Size of spores, basidia, cheilocystidia and pleurocystidia, as well as pileipellis elements dimensions were correspondingly based on: 51, 31, 31, 21 and 21 measurements. Drawings were made with the aid of a drawing tube under an oilimmersion objective. The collected specimen is deposited in the Herbarium of the Museum of Natural History, Wrocław University, Wrocław (WRSL).

\section{RESULTS}

The occurrence of Volvariella caesiotincta carpophore was discovered on 12th July 2002 in Las Wojnowski municipal forest. The forest area where the fungus occurred is surrounded by fields under cultivation and is situated in the eastern part of Wrocław (Fig. 1). A potential plant community there in the area is elm-ash community (Matuszkiewicz 2007). Analysis of phytosociological relevés made within the area did not allow to determine an unambiguous association character of the forest community. Representative plants of Ficario-Ulmetum minoris Knapp 1942 em. J.Mat. 1976 association have been left their stamp on floristic composition profile, but distinct participation of key species from Carpinion betuli Issl. $1931 \mathrm{em}$. Oberd. 1953 alliance is evident too. The dominant species of the tree layer at the community where the fungus occurred are: Carpinus betulus, Fraxinus excelsior, Quercus robur and Tilia cordata. The shrub layer includes mainly: Carpinus betulus, Corylus avellana, Sambucus nigra and Padus avium. In the herb layer, Ficaria verna, Anemone nemorosa, Milium effusum and Maianthemum bifolium grow abundantly during spring season.

In the course of field working only one specimen of Volvariella caesiotincta was found. The carpophore of the fungus occupied the base part of distinct rotten log of Quercus robur. Further observations at the investigated site were conducted in July 


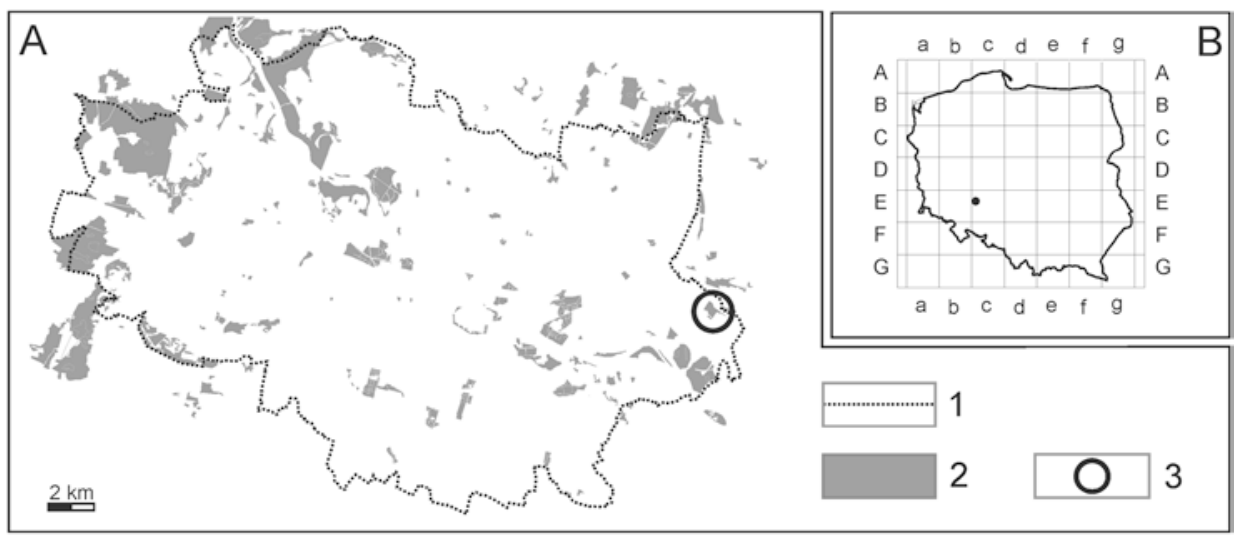

Fig. 1. The location of the Volvariella caesiotincta: A - site in Wrocław; B - in Poland (based on a $100 \mathrm{~km}$ ATPOL grid); 1 - urban boundary, 2 - municipal forests and parks, 3 - locality of the species.

2003 and July 2004, but no V. caesiotincta carpophores were observed. The location of the species has been carefully marked and will be monitored in the future.

\section{DESCRIPTION OF THE SPECIMENS}

Volvariella caesiotincta P.D. Orton, Bull. mens. Soc. linn. Lyon 43: 319. 1974. Pluteaceae, Agaricales, Agaricomycetidae, Agaricomycetes, Basidiomycota, Dikarya, Fungi (Kirk et al. 2008; Hibbett et al. 2007).

MACROSCOPIC AND MICROSCOPIC CHARACTERS. Pileus $44 \times 39 \times 11.5 \mathrm{~mm}$, applanate, with an obtuse umbo and slightly inflexed margin, fleshy, surface finely radially fibrillose at margin to nearly strigose at the central part, dry and mat, \pm white, greish white, paler towards margin, with slight olivaceous tinge at the central part. Lamellae crowded, free, thin, broadly ventricose, rounded at margin of pileus, flesh-pink, with whitish flocculose edge. Stipe $52 \times 5.0 \mathrm{~mm}$, tapering upwards, with slightly bulbous base (up to c. $9.5 \mathrm{~mm}$ wide) enclosed by 3-lobed, greyish white to greyish brown, membranous volva (up to c. $21 \mathrm{~mm}$ high), solid, extremely fragile, glabrous to fibrillose-striate, translucent white. Context in pileus and stipe quite compact, fragile, whitish (Fig. 2). Smell rather strong, reminding Geranium robertianum odour. Taste moderately strong, unpleasant, rather astringent. Colour of spore print was not recorded.

Spores (6.2) $6.7 \pm 0.3(7.7) \times(4.2) 4.6 \pm 0.3(5.4) \mu \mathrm{m}, \mathrm{Q}=(1.21) 1.46 \pm 0.08$ (1.64), ellipsoid, oblong to oblong-ovoid, not ornamented. Basidia 21-28 $\times 6.5-9.0 \mu \mathrm{m}$, clavate, with 4 sterigmata, without basal clamp. Cheilocystidia 34-65 $\times 9.6-19 \mu \mathrm{m}, \pm$ clavate, frequently with apical papilla or up to $15 \mu \mathrm{m}$ long, finger-like appendage, or lageniform to utriform. Pleurocystidia $35-46 \times 10-25 \mu \mathrm{m}$, clavate, lageniform to utriform, very rare. Pileipellis: a cutis, made up of cylindrical elements (15-27 $\mu \mathrm{m}$ width), with intracellular, pale (yellow) pigment (Fig. 3). Observed septa without clamps. 


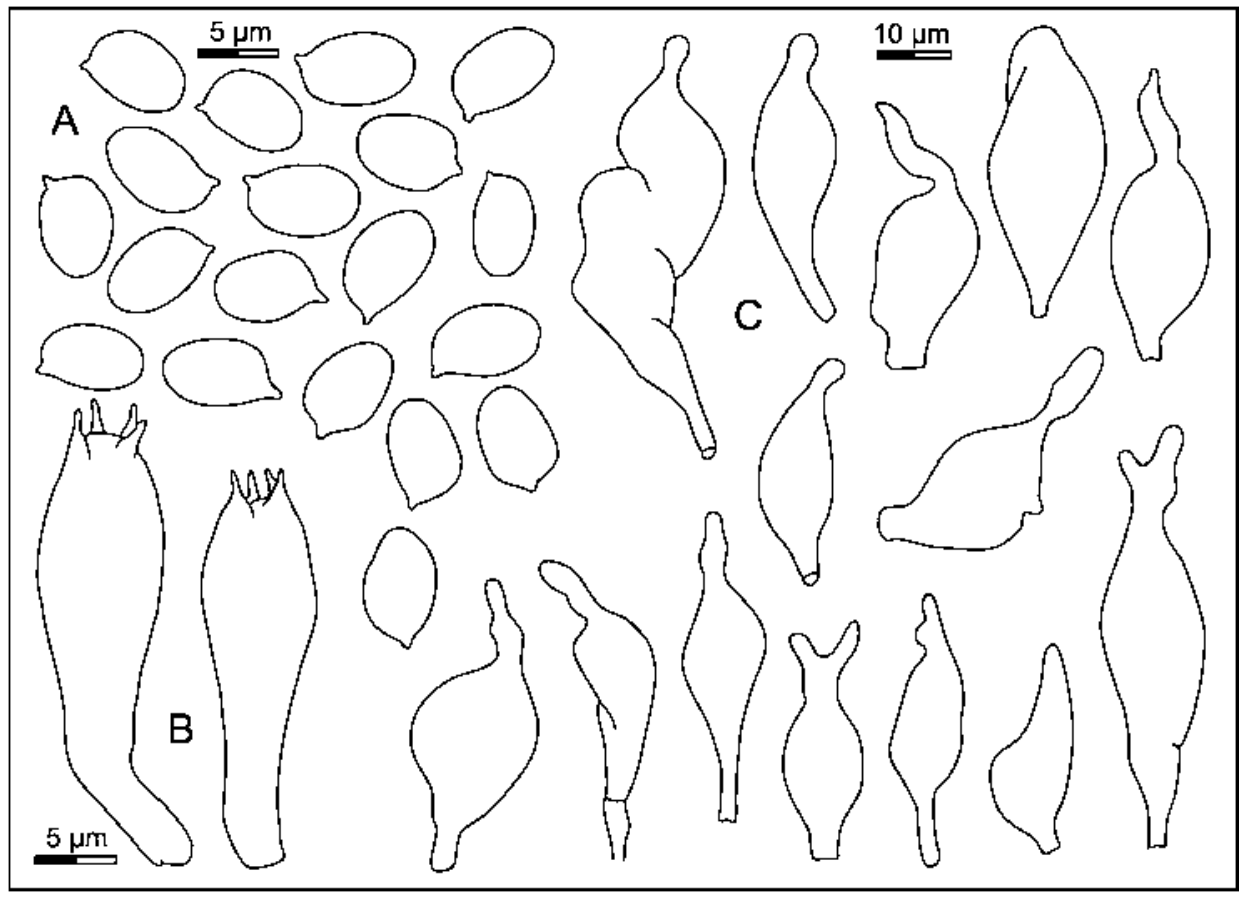

Fig. 3. A-spores; B - basidia; C-cheilocystidia of Volvariella caesiotincta recorded in Wrocław (drawn by M. Halama).

Material exAmined. Wrocław (Poland), Las Wojnowski Forest, distinctly rotten log of Quercus robur, 12.07.2002, coll. M. Halama, WRSL.

TAXONOMICAL REMARKS. Nearly identical carpophores produces $V$. murinella, which can be separated with certainty from $V$. caesiotincta only on the base of microscopic characters. As it was emphasized by Breitenbach et Kränzlin (1995), in contrast to V.caesiotincta, V. murinella has cheilocystidia without the conspicuous finger-like and occasionally forked apical projection. Moreover, there is an ecological difference between the two species, i.e. V. caesiotincta grows on wood or is associated with wood, while the latter occurs on humus rich soil or remains of leaves or plants and among grass. Volvariella pusilla var. taylorii (Berk. \& Broome) Boekhout also resembles $V$. caesiotincta, from which it mainly differs in habitat (terrestrial fungus occurs mainly in grasslands on clayey soil), sweet and fungoid smell, indeterminate taste, and smaller size of carpophores (cf. Boekhout 1990; Skirgiełło 1999).

HABITAT AND GENERAL Distribution. Carpophores of Volvariella caesiotincta almost exclusively appears in summer to early fall season (July-September), solitary or more rarely gregarious, on distinctly rotten wood (of optimal and terminal decay phase) of broadleaved trees, i.e. on logs and stumps of Carpinus, Fagus, Tilia, Ulmus, Fraxinus and Quercus (Boekhout 1990; Krieglsteiner 2003).

Volvariella caesiotincta is reported from North Africa (Marocco) and Europe. In Europe it is widely distributed and is known from Spain, Italy, France, Liechtenstein, Austria, Hungary (Krieglsteiner 2003), Holland (Boekhout 1990), Great 
Britain (B.M.S. 2004), Switzerland (Breitenbach, Kränzlin 1995), Czech Republic (Antonín et al. 1995), Slovakia (Lizoň 2001), Germany (Krieglsteiner 1991), Denmark (Vesterholt et al. 1998), Sweden (Gärdenfors 2005), Norway (Bendiksen et al. 1999) and Finland (Rassi et al. 2001). The fungus is recognized all over as a rare species (Krieglsteiner 2003) and is included in the red lists of number of European countries. For example, in Sweden it is included in indeterminate category of threat (DD) (Gärdenfors 2005), in Slovakia - in near threatened category (LR) (Lizoň 2001), in Denmark and Norway - in vulnerable category (V) (Vesterholt et al. 1998; Bendiksen et al. 1999), in Finland - is treated as critically endangered species (category CR) (Rassi et al. 2001) and in Germany it appears in group of very rare species (category R) (Benkert at al. 1992).

Acknowledgment. Financial support within a grant no. 6P04F01720 awarded by the State Committee for Scientific Research is gratefully acknowledged.

\section{REFERENCES}

Antonín V., Fellner R., Herink J., Lazebníček J., Lizoň P., Kotlaba F., Šebek S. 1995. Huby. (In:) F. Kotlaba (ed.). Červená kniha ohrozených a vzácnych rastlín a živočíchov SR a ČR (Sinice a riasy, Huby, Lišajníky, Machorasty). 4. Príroda, Bratislava: 30-119.

Bendiksen E., Brandrud T.E., Jordal J.B., Gulden G., Hoiland K., Zimmermann V. 1999. SOPP (Ascomycetes/Basidiomycetes). (In:) S. Lier-Hansen (ed.). Nasjonal rodliste for truete arter i Norge 1998 (Norwegian Red List 1998) - DN-rapport 1999-3, Trondheim: 24-39.

Benkert D., Dörfelt H., Hardtke H.-J., Hirsch G., Kreisel H., Krieglsteiner G. J., Lüderitz M., Runge A., Schmid H., Schmitt J.A., Winterhoff W., Wöldecke K., Zehfuß H.-D., Einhellinger A., Groß G., Große-Brauckmann H., Nuss I., Wölfel G. 1992. Rote Liste der gefährdeten Großpilze in Deutschland. Deutsche Gesellschaft für Mykologie e.V. et Naturschutzbund Deutschland e.V. (NABU), IHW-Verlag, Eching, 144 pp.

Boekhout T. 1990. Genus Volvariella. (In:) C. Bas, Th.W. Kuyper, M.E. Noordeloos, E.C. Vellinga (eds). Flora Agaricina Neerlandica. Critical monographs on families of agarics and boleti occuring in the Netherlands. 2. A. Balkema, Rotterdam: 56-64.

Breitenbach J., Kränzlin F. 1991. Fungi of Switzerland. A contribution to the knowledge of the fungal flora of Switzerland. 3. Boletes and Agarics. Verlag Mykologia, Luzern, 364 pp.

Breitenbach J., Kränzlin F. 1995. Fungi of Switzerland. A contribution to the knowledge of the fungal flora of Switzerland. 4. Agarics . Verlag Mykologia, Luzern, $368 \mathrm{pp}$.

British Mycological Society. 2004. The Checklist of British Fungi. Published on the WEB site: http://194.203.77.69/fieldmycology/GBCHKLST/ [gained access: 23-09-2004].

Gärdenfors U. (ed.) 2005. Rödlistade arter i Sverige 2005. (The 2005 Red List of Swedish Species). ArtDatabanken, SLU, Uppsala, 496 pp.

Hibbett S.A., Binder M., Bischoff J.F., Blackwell M., Cannon P.F., Eriksson O.E., Huhndorf S., James T., Kirk P.M., Lücking R., H. Lumbsch T., Lutzoni F., Matheny P.B., Mclaughlin D.J., Powell M. J., Redhead S., Schoch C.L., Spatafora J.W., Stalpers J.A., Vilgalys R., Aime M.C., Aptroot A., Bauer R., Begerow D., Benny G.L., Castlebury L.A., Crous P.W., Dai Y.-C., Gams W., Geiser D. M., Griffith G.W., Gueidan C., Hawksworth D.L., Hestmark G., Hosaka K., Humber R.A., Hyde K.D., Ironside J.E., Koljalg U., Kurtzman C.., Larsson K.-H., Lichtwardt R., Longcore J., Miądlikowska J., Miller A., Moncalvo J.-M., Mozley-Standridge S., Oberwinkler F., Parmasto E., Reeb V., Rogers J.D., Roux C., Ryvarden L., Sampaio J.P., Schüßler A., Sugiyama J., Thorn R. G., Tibell L., Untereiner W.A., Walker C., Wang Z., Weir A., Weiss M., White M.M., Winka K., Yao Y.-J., Zhang N. 2007. A higherlevel phylogenetic classification of the Fungi. Mycological Research 111: 509-547.

Horak E. 2005. Röhrlinge und Blätterpilze in Europa. Spectrum Academischer Verlag, Heidelberg, 575 pp.

Karasiński D. 2006. Grzyby polskie: Volvariella caesiotincta. Published on the WEB site: http://www.grzyby.strefa.pl/Volvariella_caesiotincta.html [gained access: 11-2008]. 
Kirk P.M., Cannon P.F., David J.C., Stalpers J.A. (eds). 2008. Ainsworth \& Bisby's Dictionary of Fungi, 10th ed. CABI Bioscience, Egham, 771 pp.

Krieglsteiner G. J. 1991. Verbreitungsatlas der Großpilze Deutschlands (West). 1. Ständerpilze. Teil B: Blätterpilze. Eugen Ulmer GmbH \& Co., Stuttgart, 1016 pp.

Krieglsteiner G.J. 2003. Pluteaceae. (In:) G. J. Krieglsteiner (ed.). Die Großpilze Baden-Württembergs. 4. Ständerpilze: Blätterpilze. II., Verlag Eugen Ulmer GmbH \& Co., Stuttgart: 243-287.

Lizoň P. 2001. Červený Zoznam Húb Slovenska 3. Verzia. December 2001 (Red list of fungi of Slovakia. The third draft. December 2001). (In:) D. Baláž, K. Marhold, P. Urban (eds). 2001. Červený zoznam rastlín a živo íchov Slovenska, Ochrana Prírody, 20 (supplement): 6-13.

Matuszkiewicz J. M. 2007. Zespoły leśne Polski. Wydawnictwo Naukowe PWN, Warszawa, 360 pp.

Mirek Z., Piękoś-Mirkowa H., Zając A., Zając M. 2002. Flowering plants and pteridophytes of Poland. A checklist. Krytyczna lista roślin naczyniowych Polski. (In:) Z. Mirek (ed.). Biodiversity of Poland. 1. W. Szafer Institute of Botany, Polish Academy of Sciences, Kraków, 442 pp.

Rassi P., Alanen A., Kanerva T., Mannerkoski I. (eds). 2001. Suomen lajien uhanalaisuus 2000 (The 2000 Red List of Finnish species). Ympäristöministeriö i Suomen ympäristökeskus (Ministry of the Environment and Finnish Environment Institute), Helsinki, $432 \mathrm{pp}$.

Singer R. 1986. The Agaricales in Modern Taxonomy. 4th ed. Koeltz Scientific Books, Koenigstein, 981 pp.

Skirgiełło A. 1999. Flora Polski. Grzyby (Mycota). 27: Łuskowcowate (Pluteaceae). W. Szafer Institute of Botany, Polish Academy of Sciences, Kraków, 79 pp.

Vellinga E.C. 1988. Glossary. (In:) C. Bas, Th. W. Kuyper, M. E. Noordeloos, E. C. Vellinga (eds). Flora Agaricina Neerlandica. Critical monographs on families of agarics and boleti occurring in the Netherlands. 1. A. Balkema, Rotterdam: 54-64.

Vesterholt J., Lange Ch., Heilmann-Clausen J., Lassoe Th., Rald E. 1998. Svampe. (In:) M. Stoltze, S. Pihl (eds). Rodliste 1997 over planter og dyr i Danmark. Miljo- og Energiministeriet. Danmarks Miljo undersogelser og Skov- og Naturstyrelsen: 30-54.

Wojewoda W. 2003. Checklist of Polish larger Basidiomycetes. Krytyczna lista wielkoowocnikowych grzybów podstawkowych Polski. (In:) Z. Mirek (ed.). Biodiversity of Poland. 7. W. Szafer Institute of Botany, Polish Academy of Sciences, Kraków.

Wojewoda W., Ławrynowicz M. 2006. Red list of the macrofungi in Poland. Czerwona lista grzybów wielkoowocnikowych w Polsce. (In:) Z. Mirek, K. Zarzycki, W. Wojewoda, Z. Szeląg (eds). Red list of plants and fungi in Poland. W. Szafer Institute of Botany, Polish Academy of Sciences, Kraków: $55-70$.

\section{Volvariella caesiotincta, nowy gatunek dla mikobioty Polski}

\section{Streszczenie}

W artykule przedstawiono pierwsze w Polsce stanowisko pochwiaka błękitnawego Volvariella caesiotincta. Dnia 22 lipca 2002 roku znaleziono owocnik V. caesiotincta na silnie zbutwiałej kłodzie Quercus robur w zbiorowisku grądowo-łęgowym na terenie lasu Lasu Wojnowskiego we Wrocławiu. W pracy przedstawiono charakterystykę cech makroskopowych i mikroskopowych zebranego okazu, zaprezentowano charakterystykę siedliskową odnotowanego stanowiska, a także przybliżono specyfikę taksonomiczną, ekologiczną i chorologiczną odnotowanego gatunku. 


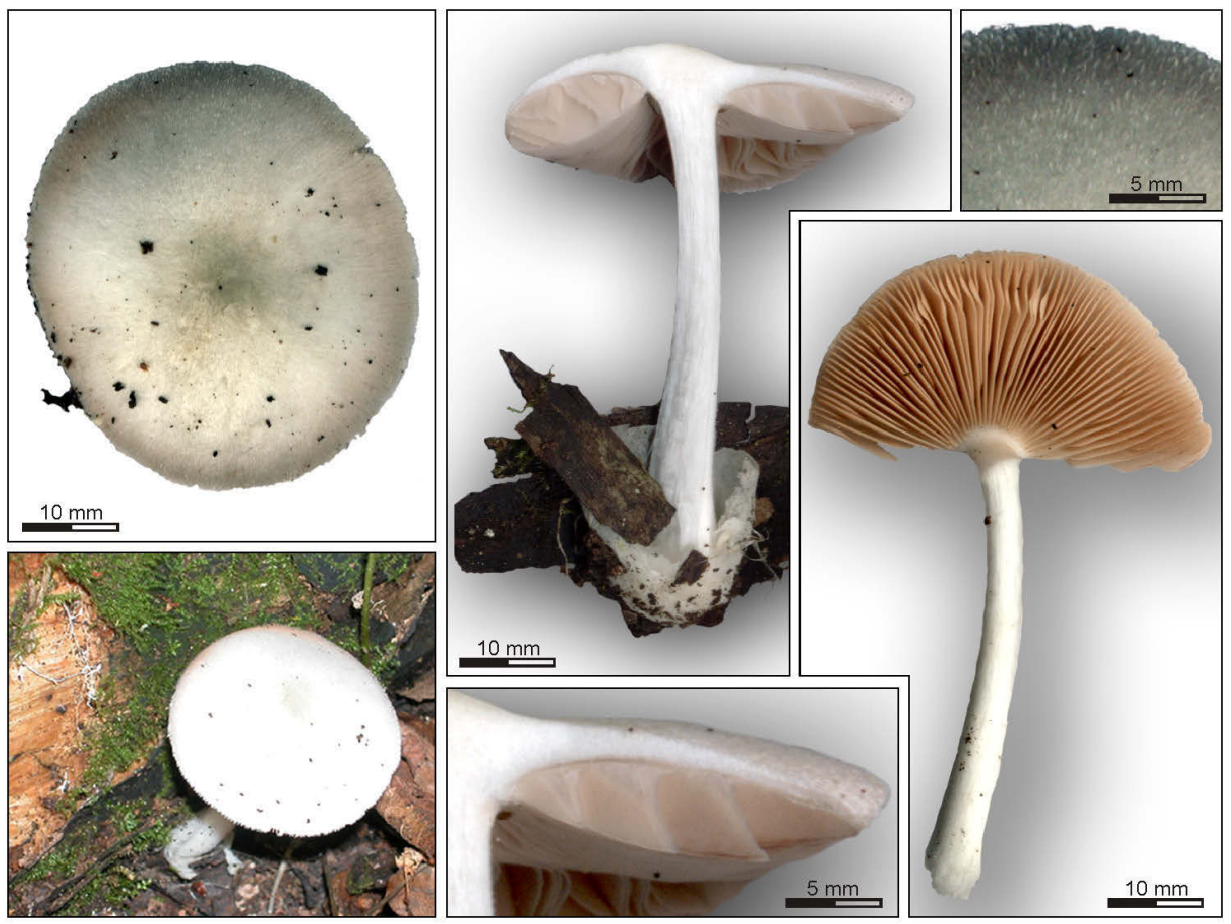

Fig. 2. Fruitbody of Volvariella caesiotincta recorded in Wrocław (22. July 2002; photo and scans by M. Halama). 